\title{
Do covers influence the capture efficiency of pitfall traps?
}

\author{
SAscha BUCHHOLZ ${ }^{1}$ and Karsten HANNIG ${ }^{2}$ \\ ${ }^{1}$ Department of Community Ecology, Institute of Landscape Ecology, University of Münster, Robert-Koch-Str. 26, \\ 48149 Münster, Germany; e-mail: saschabuchholz@uni-muenster.de \\ ${ }^{2}$ Dresdener Str. 6, 45731 Waltrop, Germany
}

Key words. Araneae, Carabidae, Formicidae, invertebrate sampling, methodology

\begin{abstract}
Pitfall traps are widely used in terrestrial ecology to capture ground-dwelling arthropods. In order to determine the effect of covers placed over pitfall traps on their efficiency at capturing of spiders, carabid beetles and ants, four types of pitfall trap were sunk into the ground at dry grassland sites: three pitfall traps were not covered, three were covered with white, three with green and three with black plastic covers. The total catch was 9,364 spiders, 4,352 carabid beetles and 4,157 ants. The distribution of species of spiders and carabid beetles, and the total catch of spiders, carabid beetles and ants did not differ significantly among the four types of trap. Therefore, covers do not appear to affect the capture efficiency of pitfall traps.
\end{abstract}

\section{INTRODUCTION}

Dahl $(1896,1907)$ was the first to describe a trap for collecting ground-dwelling arthropods. Since Barber (1931) first used pitfall traps they have been widely used in terrestrial ecology. A detailed description of the technique is given by Balogh (1958) and new developments presented by Melber (1987) and Grell (1997). In general, pitfall traps consist of cups or jars containing preserving and killing fluids that are embedded flush with the ground surface. Despite criticisms (Bombosch, 1962; Topping \& Sunderland, 1992; Topping, 1993), pitfall traps are well suited for investigating the occurrence and abundance of ground-dwelling arthropods, such as spiders and beetles (Tretzel, 1955; Luff, 1975; Adis, 1979; Churchill, 1993). Pitfall trapping is inexpensive, easy to handle, time-efficient and produces large species-rich samples suitable for statistical analyses (Spence \& Niemelä, 1994). Apart from the design of the trap (Luff, 1975; Wagge, 1985) many features may influence their catching efficiency. For example, Greenslade (1964) and Ward et al. (2001) revealed the influence of the surrounding vegetation and position of the trap, and Mitchell (1963), Ericson (1979) and Honek (1988) the effect of weather and microclimate. Several studies compared the influence of different fluids used as killing agents and preservatives (Luff, 1968; Greenslade \& Greenslade, 1971; Holopainen \& Varis, 1986; Pekár, 2002; Schmidt et al., 2006; Jud \& Schmidt-Entling, 2008).

To protect pitfalls against rain or leaves, many entomologists and arachnologists cover their traps with metal or plastic plates. On the other hand, particularly in open habitats such as dry grassland, pitfall traps are frequently not covered because the covers might attract the attention of vertebrates, such as sheep and goats, which may destroy the traps. To date, differences between the sampling efficiency of open and covered pitfall traps has received little attention. Furthermore, nothing is known about the potential effect of differently coloured covers. Hence, the aim of the present study is to compare the capture efficiency of open and covered pitfall traps.

\section{MATERIAL AND METHODS}

Five dry grassland sites (Corynephoretum - vegetation structure: mean coverage (median) of herbal layer $=20 \%$, moss $=$
$40 \%$, litter $=10 \%$, bare ground $=40 \%$, height of herbal layer $=$ $10 \mathrm{~cm}$; no shading) located near Münster $\left(51^{\circ} 57^{\prime} 46,63 \mathrm{~N}\right.$, $\left.7^{\circ} 37^{\prime} 43,33 \mathrm{E}\right)$ in North Rhine-Westphalia, Germany, were investigated from 15 August 2007 to 12 July 2008. The climate in this region is sub-oceanic with an average annual temperature of $7.9^{\circ} \mathrm{C}$ and average annual precipitation of $758 \mathrm{~mm}$ (Murl NRW, 1989).

At each site 12 pitfall traps (plastic jar, diameter $=9 \mathrm{~cm}$, height $=12 \mathrm{~cm}$ ) were sunk into the ground $5 \mathrm{~m}$ apart. Each trap was filled to a depth of about $3 \mathrm{~cm}$ with $3 \%$ formalin solution plus some detergent. Three traps were not covered and $3 \mathrm{~cm}$ above nine traps were placed either a white, green or black plastic cover $(14 \times 14 \mathrm{~cm})$ (three of each colour $)$ as suggested by Tretzel (1955). Thus, there were four treatments with five replicates. The traps were emptied once a month, when the catches were transferred to ethanol $(75 \%)$. Spiders, carabid beetles and ants were counted. Additionally, the species of all spiders and carabid beetles were determined. To identify any differences in the catching efficiency of the four types of trap, a permutation one-way analysis of variance (ANOVA) was performed using PERMDIST (Anderson, 2004). The factor "cover" with four levels (none, white, green, black) was tested for the three dependent variables Araneae (Lycosidae, Linyphiidae, Gnaphosidae, Thomisidae, Theridiidae), Carabidae and Formicidae. Permutation tests are widely used for testing hypotheses and other statistical applications in biology (Manly, 1997). In principle, they compare an observed test statistic with a distribution that is generated by randomly reordering the data values. Compared to more common statistical methods, permutation tests have several advantages: they are valid even if the samples were not collected at random, and allow both the choice of an appropriate test statistic and nonstandard test statistics (Manly, 1997; Anderson, 2001).

To test for possible differences in the species composition of the catches of the four types of pitfall traps, the numbers of 45 spider and 37 carabid beetle species caught were subjected to non-metric multidimensional scaling (NMDS) using VEGAN (Oksanen et al., 2008) and MASS packages (Ripley, 2008) in software package R 2.8.1 (http://www.r-project.org). Sporadic species (cf. Engelmann, 1978), which occurred at frequencies of less than $0.32 \%$ per trap type, were omitted from the statistical analyses. For ordination the abundances of each species were 
TABLE 1. Differences in the medians of the catches of Araneae, Carabidae and Formicidae by open and covered (white, green, black covers) pitfall traps. All variables were square-root transformed before analysis using PERMDISP (one-way ANOVA; 499 permutations).

\begin{tabular}{|c|c|c|c|c|c|c|}
\hline \multirow{2}{*}{$\begin{array}{l}\text { Tested } \\
\text { variable }\end{array}$} & \multicolumn{3}{|c|}{ covered } & \multirow{2}{*}{$\begin{array}{l}\text { open } \\
\mathrm{n}=5\end{array}$} & \multicolumn{2}{|c|}{ ANOVA } \\
\hline & $\begin{array}{l}\text { white } \\
\mathrm{n}=5\end{array}$ & $\begin{array}{l}\text { green } \\
\mathrm{n}=5\end{array}$ & $\begin{array}{l}\text { black } \\
\mathrm{n}=5\end{array}$ & & $\mathrm{~F}$ & $\mathrm{P}$ \\
\hline \multicolumn{7}{|l|}{ Araneae } \\
\hline individuals & 61.4 & 59.8 & 66.1 & 63 & 0.53 & 0.65 \\
\hline species & 31 & 36 & 34 & 36 & 0.08 & 0.94 \\
\hline \multicolumn{7}{|l|}{ Carabidae } \\
\hline individuals & 54.3 & 57.2 & 40.9 & 67.5 & 1.76 & 0.20 \\
\hline species & 16 & 16 & 13 & 29 & 0.21 & 0.85 \\
\hline \multicolumn{7}{|l|}{ Formicidae } \\
\hline individuals & 36.7 & 26.7 & 169.6 & 17.3 & 2.37 & 0.11 \\
\hline
\end{tabular}

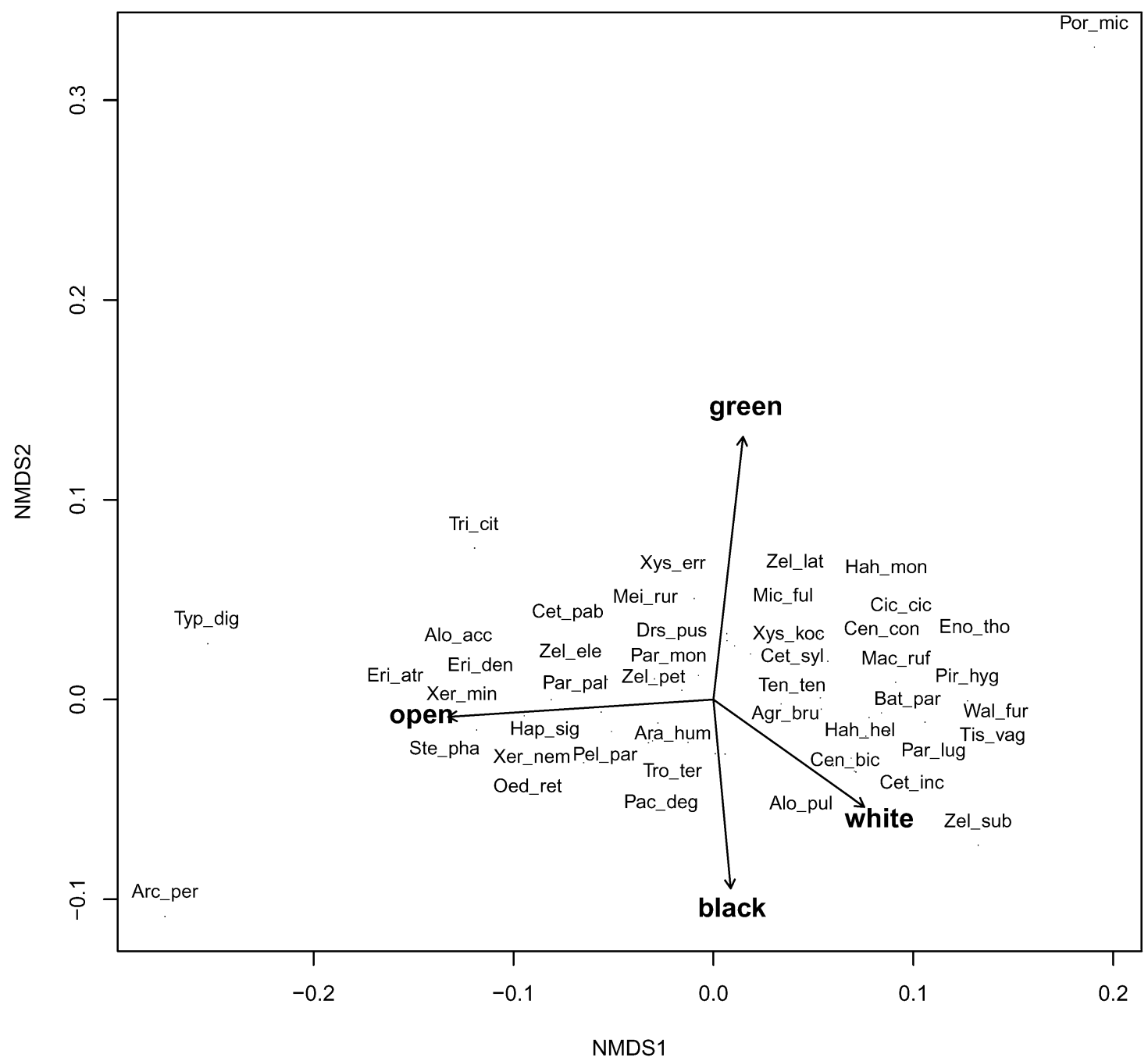

Fig. 1. Non-metric multidimensional scaling (NMDS) ordination (stress $=0.06$ ) based on Bray-Curtis dissimilarity matrix of the spiders caught in the four types of pitfall traps (open, white, green or black cover). Significance of differences in species distribution between open and covered pitfall traps: $\mathrm{p}=0.23$. Abbreviated species names (in alphabetical order): Agr_bru $=$ Agroeca brunnea, Alo_acc $=$ Alopecosa accentuata , Alo_pul $=$ Alopecosa pulverulenta, Ara_hum $=$ Araeoncus humilis, Arc_per $=$ Arctosa perita, Bat_par $=$ Bathyphantes parvulus, Cen bic $=$ Centromerita bicolor, Cen_con $=$ Centromerita concinna, Cet inc $=$ Centromerus incilium, Cet_pab $=$ Centromerus pabulator, Cet_syl $=$ Centromerus sylvaticus, Cic_cic $=$ Cicurina cicur, Drs_pus $=$ Drassyllus pusillus, Eno_tho = Enoplognatha thoracica, Eri_atr = Erigone atra, Eri_den $=$ Erigone dentipalpis, Hah_hel $=$ Hahnia helveola, Hah_mon $=\bar{H}$ ahnia montana, Hap_sig $=$ Haplodrassus signifer, Mac_ruf $=$ Macrargus rufus, Mei_rur $=$ Meioneta rurestris, Mic_ful

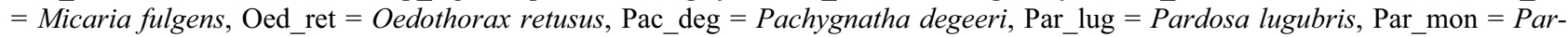

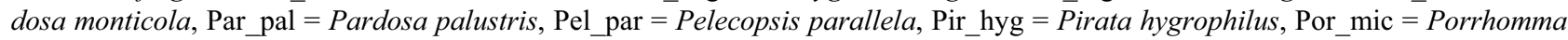
microphthalmum, Ste_pha $=$ Steatoda phalerata, Ten_ten $=$ Tenuiphantes tenuis, Tis_vag $=$ Tiso vagans, Tri_cit $=$ Trichopterna cito, Tro_ter $=$ Trochosa terricola, Typ_dig $=$ Typhochrestus digitatus, Wal_fur $=$ Walckenaeria furcillata, Xer_min $=$ Xerolycosa miniata, Xer_nem $=$ Xerolycosa nemoralis, Xys_err $=$ Xysticus erraticus, Xys_koc $=$ Xysticus kochi, Zel_ele $=\bar{Z}$ Zelotes electus, Zel_lat $=$ Zelotes latreillei, Zel_pet $=$ Zelotes petrensis, Zel_sub $=$ Zelotes subterraneus. 
TABLE 2. Differences in the medians of frequent ( $>1 \%)$ spider families caught in open and covered (white, green, black covers) pitfall traps. All variables were square-root transformed before analysis using PERMDISP (one-way ANOVA; 499 permutations).

\begin{tabular}{|c|c|c|c|c|c|c|}
\hline \multirow[b]{2}{*}{ No. of } & \multicolumn{3}{|c|}{ covered } & \multirow[b]{2}{*}{$\begin{array}{l}\text { open } \\
\mathrm{n}=5\end{array}$} & \multicolumn{2}{|c|}{ ANOVA } \\
\hline & $\begin{array}{l}\text { white } \\
\mathrm{n}=5\end{array}$ & $\begin{array}{l}\text { green } \\
\mathrm{n}=5\end{array}$ & $\begin{array}{l}\text { black } \\
\mathrm{n}=5\end{array}$ & & $\mathrm{~F}$ & $\mathrm{P}$ \\
\hline Lycosidae & 44.7 & 48.2 & 51.3 & 42.2 & 0.1 & 0.99 \\
\hline Linyphiidae & 16.6 & 13.6 & 15.7 & 25.0 & 0.9 & 0.49 \\
\hline Gnaphosidae & 4.2 & 4.1 & 3.6 & 3.4 & 2.5 & 0.08 \\
\hline Thomisidae & 0.4 & 3.1 & 2.5 & 3.5 & 1.7 & 0.19 \\
\hline Theridiidae & 0.8 & 0.9 & 1.1 & 1.2 & 1.0 & 0.42 \\
\hline
\end{tabular}

square root transformed. NMDS is an iterative ordination method, which places samples in k-dimensional space using the ranked distances between them. For the statistical background of this technique see Clarke (1993), McCune \& Grace (2002) and Leyer \& Wesche (2007). In this study, the ordination was based on the Bray-Curtis distance measure. A maximum of 10

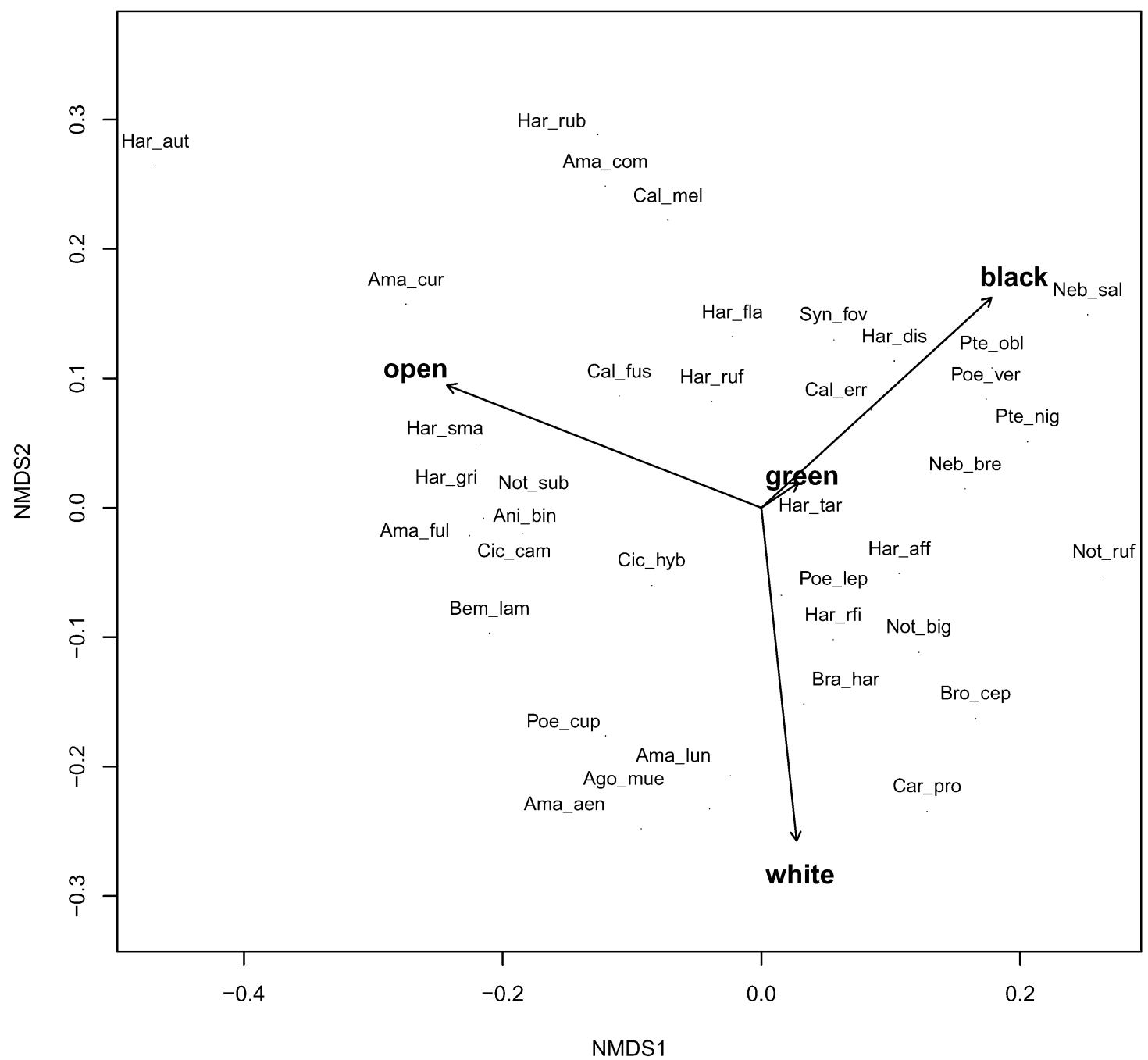

Fig. 2. Non-metric multidimensional scaling (NMDS) ordination (stress $=0.06$ ) based on Bray-Curtis dissimilarity matrix of the carabid beetles caught in four types of pitfall traps (open, white, green or black covers). Significance of differences in species distribution between open and covered pitfall traps: $p=0.25$. Abbreviated species names (in alphabetical order): Ama aen $=$ Amara aenea, Ama_com = Amara communis/makolskii, Ama_cur = Amara curta, Ama_ful = Amara fulva, Ama_lun = Amara lunicollis, Ago mue = Agonum mülleri, Ani bin = Anisodactylus binotatus, Bem lam $=$ Bembidion lampros, Bra har $=$ Bradycellus harpalinus, Bro_cep $=$ Broscus cephalotes, Cal_err $=$ Calathus erratus, Cal_fus $=$ Calathus fuscipes, Cal_mel = Calathus melanocephalus, Car_pro $=$ Carabus problematicus, Cic_cam $=$ Cicindela campestris, Cic_hyb $=$ Cicindela hybrida, Har_aff $=$ Harpalus affinis, Har aut $=$ Harpalus autumnalis, Har dis $=$ Harpalus distinguendus, Har fla $=$ Harpalus flavescens, Har gri $=$ Harpalus griseus, Har_rub $=$ Harpalus rubripes, Har_ruf $=$ Harpalus rufipalpis, Har_rfi $=$ Harpalus rufipes, Har_sma $=$ Harpalus smaragdinus, Har tar $=$ Harpalus tardus, Neb bre $=$ Nebria brevicollis, Neb_sal $=$ Nebria salina, Not_big $=$ Notiophilus biguttatus, Not_ruf $=$ Notiophilus rufipes, Not_sub $=$ Notiophilus substriatus, Poe_cup $=$ Poecilus cupreus, Poe_lep $=$ Poecilus lepidus, Poe_ver $=$ Poecilus versicolor, Pte_nig $=$ Pterostichus niger, Pte_obl $=$ Pterostichus oblongopunctatus, Syn_fov $=$ Syntomus foveatus. 
random starts in search of a stable solution was used for a 2-dimensional model. Then the trap types were fitted as predictor variables onto the ordination. To assess the affect of the cover on the catches, p-values were calculated using a MonteCarlo procedure (999 permutations).

\section{RESULTS}

A total of 9,364 spiders belonging to 127 species (comprising 5,388 Lycosidae, 2,508 Linyphiidae, 576 Gnaphosidae, 420 Thomisidae, 129 Theridiidae and 343 specimens from 13 other families), 4,352 carabid beetles belonging to 70 species and 4,157 ants were caught. Neither the number of individuals nor the number of spider species differed significantly between trap types (Table 1). Within the Araneae, the five most frequent families Lycosidae, Linyphiidae, Gnaphosidae, Thomisidae and Theridiidae were tested (Table 2). While most medians showed only small differences among treatments, the median of linyphiid spiders was higher in open pitfall traps. Thomisidae occurred with a lower median in traps with white covers. Nevertheless, the differences were not significant. The numbers of species of carabid beetles and individuals did not differ significantly between open pitfall traps and those with white, green or black covers. Despite the fact that pitfall traps with black covers had a remarkably high median for catches of ants, there were no significant differences in the catches.

Although there were no significant differences in the distribution of species of spider among the trap types $(p=0.23)$ the ordination plot indicated slightly higher frequencies of typical open habitat spiders in open pitfall traps (e.g. Alopecosa accentuata, Artcosa perita, Erigone atra, Typhochrestus digitalis) and typical inhabitants of high vegetation and forest habitats mainly in the covered traps (e.g. Cicurina cicur, Macrargus rufus, Pardosa lugubris, Pirata hygrophilus) (Fig. 1). The ordination also did not indicate a significant response to trap type $(p=0.25)$ of carabid beetle species (Fig. 2). In contrast to the spider distribution, there were no hints of such differences in frequencies of open habitat and woodland beetle species in covered and open traps.

\section{DISCUSSION}

Summarising, neither the number of spider species nor the total catch of spiders, carabid beetles or ants differed significantly among the four trap types compared in this study. This indicates that covers do not affect the capture efficiency of pitfall traps. Consequently, it seems valid to compare pitfall trap results from studies that used traps with covers and those that used open traps, as long as other factors like size and shape of the pitfall traps are identical. Nevertheless, this study indicates that covers over pitfall traps may influence the spider species composition since forest species were more frequent (though not significantly) caught in covered traps. Highly mobile forest species that pass through open and heated sites might be attracted by the shaded patches beneath the covers and use them as shelter.

When working with pitfall traps it is strongly recommended that one takes into account the habitat structure and surrounding conditions (Melbourne, 1999). This study was conducted mainly in open dry grassland with sparse vegetation. The effect of covering pitfall traps might be quite different in other habitats. For example, in forests falling leaves may affect uncovered pitfall traps more than covered traps. Furthermore, there are several technical questions that remain unanswered. For example, coloured covers may change the microclimate in the immediate surroundings of the pitfall trap, since black covers might absorb light and so raise the local temperature and white covers reflect light and reduce the local temperature. Thus, it would be interesting to provide detailed measurements of local temperature (e.g. by using thermo-data loggers). In this regard, studying the impact of covers on the evaporation of the preservative solution might also be relevant. Future studies that deal with similar questions should also test how or whether large covers influence the capture efficiency as well as the species distribution.

ACKNOWLEDGEMENTS. S. Buchholz would like to thank M. Breuer for her encouragement and T. Fartmann and H. Mattes for enabling this work. We are very thankful to V. Hartmann, M. Konvicka, J. Schirmel, A. Schwerk and one anonymous referee for valuable comments on an earlier draft of the manuscript and to R. Baumgartner for linguistic revision of the text. $\mathrm{S}$. Buchholz was funded by a scholarship from the FriedrichEbert-Foundation (FES).

\section{REFERENCES}

ADIS J. 1979: Problems of interpreting arthropod sampling with pitfall traps. Zool. Anz. 202: 177-184.

ANDERSON M.J. 2001: Permutation tests for univariate or multivariate analysis of variance and regression. Can. J. Fish. Aquat. Sci. 58: 626-639.

ANDERSON M.J. 2004: PERMDISP: a FORTRAN computer program for permutational analysis of multivariate dispersions (for any two-factor ANOVA design) using permutation tests. Department of Statistics, University of Auckland, New Zealand.

BALOGH J. 1958: Lebensgemeinschaften der Landtiere. Akademie Verlag, Berlin, 560 pp.

BARBER H.S. 1931: Traps for cave-inhabiting insects. J. Elisha Mitchell Sci. Soc. 46: 259-266.

Bомвоsсн S. 1962: Untersuchungen über die Auswertbarkeit von Fallenfängen. Z. Angew. Zool. 49: 149-160.

Churchill T.B. 1993: Effects of sampling method on composition of a tasmanian coastal heathland spider assemblage. Mem. Queensl. Mus. 33: 475-481.

Clarke K.R. 1993: Non-parametric multivariate analyses of changes in community structure. Austral. Ecol. 18: 117-143.

DAHL F. 1896: Vergleichende Untersuchungen über die Lebensweise wirbelloser Aasfresser. Sitzber. Königl. Preuß. Akad. Wiss. 1896: 11-24.

DAHL F. 1907: Die mechanische Methode in Sammeln von Tieren. Zool. Anz. 31: 917-919.

EngelmanN H.-D. 1978: Zur Dominanzklassifizierung von Bodenarthropoden. Pedobiologia 18: 378-380.

ERICSON D. 1979: The interpretation of pitfall catches of Pterostichus cupreus and Pt. melanarius (Coloeoptera, Carabidae) in cereal fields. Pedobiologia 19: 320-328.

Greenslade P.J.M. 1964: Pitfall trapping as a method of studying populations of Carabidae (Coleoptera). J. Anim. Ecol. 33: 301-310.

Greenslade P. \& Greenslade P.J.M. 1971: The use of baits and preservatives in pitfall traps. J. Aust. Entomol. Soc. 10: 253-260.

Grell H. 1997: Die Flaschenfalle. Natursch. Landschaftsplan. 29: $126-127$.

Holopainen J.K. \& VARIS A.-L. 1986: Effects of a mechanical barrier and formalin preservative on pitfall catches of carabid beetles (Coleoptera, Carabidae) in arable fields. J. Appl. Entomol. 102: 440-445.

HoneK A. 1988: The effect of crop density and microclimate on pitfall trap catches of Carabidae, Staphylinidae (Coleoptera) and Lycosidae (Araneae) in cereal fields. Pedobiologia 32: 233-242. 
Jud P. \& Schmidt-Entling M.H. 2008: Fluid type, dilution, and bitter agent influence spider preservation in pitfall traps. Entomol. Exp. Appl. 129: 356-359.

Leyer I. \& Wesche K. 2007: Multivariate Statistik in der Ökologie. Springer, Berlin, $221 \mathrm{pp}$.

LuFF M.L. 1968: Some effects of formalin on the members of Coleoptera caught in pitfall traps. Entomol. Mon. Mag. 104: $115-116$

LuFF M.L. 1975: Some effects influencing the efficiency of pitfall traps. Oecologia 19: 345-357.

ManLy B.F.J. 1997: Randomization, Bootstrap and Monte Carlo Methods in Biology. Chapman \& Hall, London, 455 pp.

McCune B. \& Grace J.B. 2002: Analysis of Ecological Communities. MjM Software Design, Gleneden Beach, 300 pp.

Melber A. 1987: Eine verbesserte Bodenfalle. Abh. Naturw. Verein Bremen 40: 331-332.

Melbourne B.A. 1999: Bias in the effect of habitat structure on pitfall traps: An experimental evaluation. Austral. Ecol. 24 228-239.

Mitchell B. 1963: Ecology of two carabid beetles, Bembidion lampros (Herbst) and Trechus quadristriatus (Schrank). II. Studies on populations of adults in the field, with special reference to the technique of pitfall trapping. J. Anim. Ecol. 32: 377-392.

MURL NRW (Ministerium für Umwelt, Raumordnung und Landwirtschaft des Landes NRW) (ed.) 1989: Klima-Atlas von Nordrhein-Westfalen. MURL NRW, Düsseldorf, 51 pp.

Oksanen J., Kindt R., Legendre P., O’Hara B., Simpson G.L., Solymos P., Stevens M.H. \& Wagner H. 2008: The vegan
Package Version 1.15-0. - Online at: http://cran.r-project. org/, http://vegan.r-forge.r-project.org/ (27.04.2009).

PeKÁr S. 2002: Differential effects of formaldehyde concentration and detergent on the catching efficiency of surface active arthropods by pitfall traps. Pedobiologia 46: 539-547.

RiPLEY B. 2008: The VR Package Version 7.2-45. - Online at: http://www.stats.ox.ac.uk/pub/MASS4/ (27.04.2009).

Schmidt M.H., Clough Y., Schulz W., Westphalen A. \& TsChARNTKE T. 2006: Capture efficiency and preservation attributes of different fluids in pitfall traps. J. Arachnol. 34: $159-162$.

Spence J.R. \& Niemela J.K. 1994: Sampling carabid assemblages with pitfall traps: the madness and the method. Can. Entomol. 126: 881-894.

ToppING C.J. 1993: Behavioural responses of three linyphiid spiders to pitfall traps. Entomol. Exp. Appl. 68: 287-293.

TopPING C.J. \& SunDERLAND K.D. 1992: Limitations to the use of pitfall traps in ecological studies exemplified by a study of spiders in a field of winter wheat. J. Appl. Ecol. 29: 485-491.

TRETZel E. 1955: Technik und Bedeutung des Fallenfanges für ökologische Untersuchungen. Zool. Anz. 155: 276-287.

WAGGE B.E. 1985: Trapping efficiency of carabid beetles in glass and plastic pitfall trap containing different solutions. Fauna Norv. (B) 32: 33-36.

WARD D.F., New T.R. \& YeN A.L. 2001: Effects of pitfall trap spacing on the abundance, richness and composition of invertebrate catches. J. Insect Conserv. 5: 47-53.

Received March 11, 2009; revised and accepted June 11, 2009 